\title{
ISOLATION AND IDENTIFICATION OF HALOALKALIPHILIC HALOMONAS SP. HA1 FROM WADI EL NATRUN LAKES, EGYPT \\ Afaf Elsayed ${ }^{*}$, Nasser H. Abbas ${ }^{2}$, Hamdy A. Hassan ${ }^{2}$, Sabha M. A ${ }^{\mathbf{1}}$. \\ ${ }^{1}$ Botany Department, Faculty of Science, Menoufia University. \\ ${ }^{2}$ Genetic Engineering and Biotechnology Research Institute, Molecular Biology Department, University of Sadat City, Sadat City, Egypt.
}

Corresponding author:Afaf ELsayed

Email: afafelsayed11@yahoo.com

\section{ABSTRACT}

Haloalkaliphilic bacterial strain was isolated from Hamra lake in Wdi EL-Natrun area. The 16s rRNA sequence of this strain shows a phylogenic relationship with Gammaproteobacteria family Halomondaceae. The strain was registered in gene bank as Halomonas HA1 strain with accession number KT223026. This strain show obligatory $\mathrm{NaCl}$ requirements for growth. The optimum $\mathrm{NaCl}$ concentration was $8 \%$ and the maximum $\mathrm{NaCl}$ concentration tolerance was $20 \%$. Halomonas HA1 show extremely alkaliphilic growth pattern with optimum growth at $\mathrm{pH} 9.0$ and the maximum tolerant was at $\mathrm{pH} 11$.

Key words:Halophiles, Alkaliphiles, Gammaproteobacteria

\section{INTRODUCTION}

Wadi El Natrun is adeprssion in the sahara desert located in Egypt $90 \mathrm{~km}$ north west of Cairo, along the valley stretches a chain of seven large alkaline and hypersaline lakes, all lakes have $\mathrm{pH}$ value between 8.5 and 11 (Amany, 1999). Wadi El Natrun is considered as an aunique aquatic ecosystem and characterized by hypersaline and alkaline lakes that rich with sulphate, chloride, carbonates and sodium, also have traces from magnesium (Sayed and Abdo, 2009).

These lakes are populated by dense communities of halophilic, alkaliphilic microorganisms and the presence of halophilic Archeae, photosynthetic purple bacteria and cyanobacteria, make the water displays different shades of red, purple and green colors (Abd-el-Malek and Rizk, 1963).

The microbial diversity of Wadi El Natrun lakes is low compared to marine and aquatic environments and the lakes are dominated by three groups of bacteria, these are: Firmicutes, Bacteroidetes, Alpha and Gamma proteobacteria, and two groups of Archaea Halobacteriales and Methanosarcinales(Noha et al., 2007).

Gamma proteobacteria were more abundant in the sediment of lake Fazda, while the sediment of lake Um Risha was dominated by sigma proteobacteria. The Hamra lake, the more oxygenated one demonstrate abundance of Bacillales, Actinobacteria, verrucomicorbia Spirochates, and Gammaproteobacteria(Noha et al., 2007).

In this study we focus on isolation and identification of haloalkaliphilic from Hamra lake. Haloalkaliphilic bacteria in general possess special adapitation mechanisms to survive and grow under salinity and alkaline $\mathrm{pH}$. These properties of dual extremity make them interesting from both, fundamental research and biotechnological points of view (Feng $\boldsymbol{e t}$ al., 2005 ; Joshi, 2006).

Enzymes from extreme microbes have great potential for biocatalysis and biotransformation due to their stability under extreme conditions where other enzymes undergoes precipitation or denaturation (Singh et al., 2010). Economically important enzymes of halophiles include many hydrolytic enzymes such as DNAses, lipases, amylases, gelatinases and proteases (Kerkar, 2004).

Halophilic microorganisms use two strategies to balance their cytoplasm osmotically with their medium: the first involves accumulation of potassium chloride and exclude $\mathrm{Na}^{+}$ions from the cytoplasm, (Lanyi, 1974), the second is to 
synthesis and accumulation of organic compatible solutes that do not interfere with enzymatic activity. This strategy requires adaptation of the intracellular enzymatic machinery to the presence of salt (Ventosa et al., 1998).

\section{MATERIAL AND METHODS Sample collection}

Water samples were collected from Hamra lake in Wadi El Natrun , Egypt. pH and salt contents of water sample at time of collection was $\mathrm{pH} 10.0$ and $300 \mathrm{~g} / \mathrm{l}$ salt. The dominant cation in the lakes $\mathrm{Na}^{+}(2.1-4.5$ $\mathrm{M})$, with traces of $\mathrm{Mg}^{+2}, \mathrm{~K}^{+}$and $\mathrm{Ca}^{+2}$ each less than $0.05 \mathrm{M}$. The main anion was $\mathrm{Cl}^{-}$ $(2.1-4.5 \mathrm{M})$, with lesser amounts $\mathrm{HCO}_{3}$ and $\mathrm{CO}_{3}{ }^{2-}$.

\section{Bacterial isolation}

Bacterial strain isolation was performed by adding $10 \mathrm{ml}$ from water sample to $100 \mathrm{ml}$ nutrient broth media that supplemented with $5 \mathrm{~g} \mathrm{NaCl}$ and adjusting $\mathrm{pH}$ to 9 by adding filter sterilized $10 \%$ $\mathrm{NaHCO}_{3}$ that increase $\mathrm{pH}$ from 7.0 to 9.0 (Horikoshi, 1999). After incubation for 48h. purification was done on Nutrient agar medium with the same condition of isolation.

\section{Phenotypic characteristics and phylogenetic analysis \\ Morphological and biochemical characterization}

Phenotypic characteristics including morphological and biochemical tests were determined for the isolated strain. Colonial morphology was described by using standardmicrobiological criteria, such as shape, color, colonial elevation and margin. Cell morphology was examined by light microscopy. Gram staining was performed as described by Murray et al. (1994). Motility was analyzed by the wet-mount method. Other biochemical tests such as catalase test, oxidase test, starch hydrolysis and urea hydrolysis test were used in identification by using standard procedures and as recommended by Smibert and Krieg (1994).

\section{Phylogenetic analysis}

Phylogenetic identification of the isolate was enabled by means of sequence analysis of the $16 \mathrm{~S}$ rRNA gene. From the purified culture on nutrient agar plate, pick up on colony and transferred to nutrient broth and after incubation for 24h. , $3 \mathrm{ml}$ sample of the pure culture was centrifuged at $12,000 \mathrm{rpm}$ for 15 minutes. The supernatant was decanted and the cells were washed twice with sterilized water. The cells were resuspended in $0.5 \mathrm{ml}$ of sterilized water. Then, genomic DNA was extracted from the pure culture using a GeneJET Genomic DNA Purification Kit (Thermo Scientific). Three primers were used in the amplification of $16 \mathrm{~S}$ rRNA. These include: 27f (5'AGAGTTTGATCMTGGCTCAG-3'), 1492r (5'-TACGG(C/T)ACCTTGTTACGACTT-3'), and Bact 1098r (5'-AAGGGTTGCGCTCGTTGCG3') (Chang et al., 2000). Theoretically, amplification with $27 \mathrm{f}-1492 \mathrm{r}$ should yield 1505bp and amplification with $27 \mathrm{f}-1098 \mathrm{r}$ should yield $1108 \mathrm{bp}$ from the 16S rRNA. Amplifications with these two primer sets were used to obtain the nearly full-length sequence (1492bp) of the 16S rRNA of the isolate. PCR amplification was performed in a total volume of $50 \mu \mathrm{l}$ in Touch Screen Thermal Cycler / PCR Model: A100/A200 (Hangzhou LongGene Scientific Instruments Co., Ltd). Each PCR mixture contained $25 \mathrm{ng}$ of template DNA, $0.6 \mu \mathrm{M}$ of each primer, $1.75 \mathrm{mM} \mathrm{MgCl} 2,200 \mu \mathrm{M}$ of dNTPs, $1.25 \mathrm{U}$ of Taq polymerase in buffer A (Promega Chemicals, Madison, WI). Amplification of $16 \mathrm{~S}$ rRNA using both primer sets consisted of an initial denaturation of the genomic DNA at $94^{\circ} \mathrm{C}$ for 5 minutes, followed by 35 cycles of denaturation at $94^{\circ} \mathrm{C}$ for 1 minute, annealing at $53^{\circ} \mathrm{C}$ for 1 minute, and extension at $72^{\circ} \mathrm{C}$ for 2 minutes, and a final extension at $72^{\circ} \mathrm{C}$ for 7 minutes. PCR products were checked for expected size on $1 \%$ agarose gels. The PCR product was purified by Gene JETTM Gel Extraction kit (Thermo Scientific). After purification, a 
sample of the PCR product was sequenced in both directions, the determined $16 \mathrm{~S}$ rRNA gene nucleotide sequences were entered for BLAST searching into the Web site of NCBI (http://www.ncbi.nlm.nih.gov/blast/), and the phylogenetic tree was constructed.

\subsection{Determination of optimal} growth condition

\subsubsection{Effect of different} temperatures on the bacterial growth

To determine the optimal temperature for growth, Erlenmeyer flasks $(100 \mathrm{ml})$ each containing $10 \mathrm{ml}$ Nutrient broth media with $3 \% \mathrm{NaCl}$ and $\mathrm{pH} 8$, then each flask was inoculated with $100 \mu$ l of the bacterial strain, the flasks were agitated at 200rpm on rotary shaker at different temperature $\left(25{ }^{\circ} \mathrm{C}, 30{ }^{\circ} \mathrm{C}, 35{ }^{\circ} \mathrm{C}, 40{ }^{\circ} \mathrm{C}, 45{ }^{\circ} \mathrm{C}\right.$ and 50 $\left.{ }^{\circ} \mathrm{C}\right)$ for $48 \mathrm{~h}$. At the end of incubation period, the turbidity was measured at $600 \mathrm{~nm}$.

\section{Effect of $\mathrm{pH}$ values on the bacterial} growth

The effect of $\mathrm{pH}$ on the bacterial was measured by growing the bacterial strains on nutrient broth media with $10 \% \mathrm{NaHCO}_{3}$ that increase $\mathrm{pH}$ from 7.0 to 9.0 and with $10 \% \mathrm{NaCO}_{3}$ that increase $\mathrm{pH}$ from 9 to 11(Horikoshi, 1999). Erlenmeyer flasks $(50 \mathrm{ml})$ each containing $10 \mathrm{ml}$ Nutrient broth media with different $\mathrm{pH}$ value $(7.4,8.0,9.0$ , 10.0 and 11.0 ), Nutrient broth media contain $3 \% \mathrm{NaCl}$, and the flasks were incubated at $\left(30-35{ }^{\circ} \mathrm{C}\right)$ and $200 \mathrm{rpm}$, after $48 \mathrm{~h}$. the growth were measured.

Effect of different salt concentrations on the bacterial growth

To find out the optimum salt concentration at which growth occur, Erlenmeyer flasks $(100 \mathrm{ml})$ each containing $10 \mathrm{ml}$ Nutrient broth media and the salt concentration were adjusted from $1 \%$ to $20 \%$, and the $\mathrm{pH}$ of the media were adjusted to $\mathrm{pH} 9.0$ and each flask was inoculated with $100 \mu \mathrm{l}$ of the bacterial strain, the flasks were agitated at 200rpm on rotary shaker at $30-35^{\circ} \mathrm{C}$ for $48 \mathrm{~h}$. At the end of incubation period, the turbidity were measured at $600 \mathrm{~nm}$.

\section{RESULTS}

a. Morphological and physiolo - gical characteristics of the isolated bacteria.

A moderately halophilic alkaliphilic bacterial strain HA1 was isolated from Hamra Lake of Wadi El Natrun. The colonies were round with smooth surface, entire edges and raised, also produce creamy colonies on Nutrient agar. Gram staining of the bacteria demonstrate gram negative short motile rods. The isolate shown dark purple color as indication for positive oxidase test. The isolate was positive for catalase, starch hydrolysis but cannot hydrolysis urea to ammonia.

\section{HA1}

Phylogenetic analysis of the strain

To determine the phylogenetic position of the isolate, 16s rRNA sequence (1480 bp) of the strain HA1 was determined and deposited under GenBank accession number KT223026. When comparing the 16s rRNA sequence of strain HA1 with those in the NCBI database, results suggested that strain HA1 was phylogenetically most closely related to the Halomonas sp. and exhibited levels of $16 \mathrm{~s}$ rRNA identity of $98 \%$ with type strain Halomonas sp. strain N1 with accession number KM013953. The phylogenetic tree was constructed and showed the clusters of neighboring Halomonas sp. figure (1). 


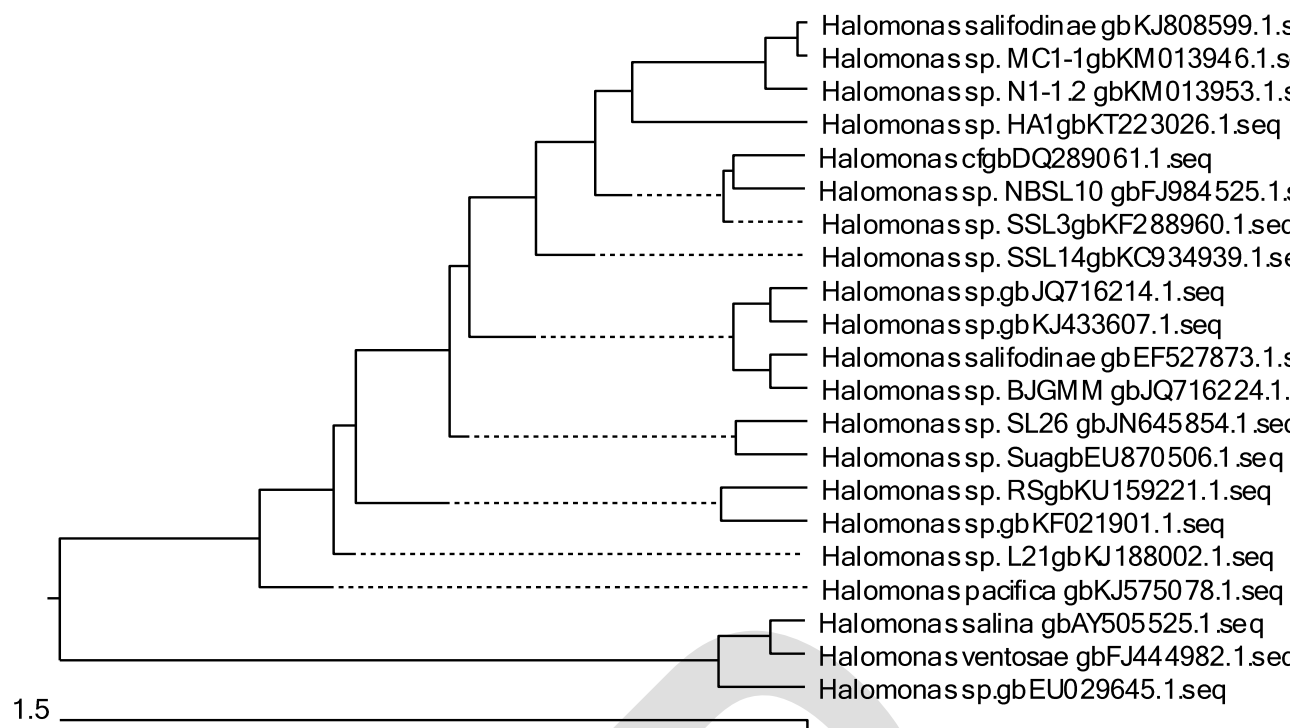

Fig (1). The phylogenetic tree based on 16s rRNA sequencesconstructed by the neighbor-joining method, showing the position of strain HA1 and representatives of some related taxa.

b. Determination of optimal growth condition

i. Effect of different temperature on bacterial growth

In this experiment the effect of different temperatures on the growth of bacterial isolate were determined by measuring absorbance at optical density $(600 \mathrm{~nm})$ from the data obtained in table (1) and fig (2), showed that the bacterial isolates can grow at different range of temperature $\left(25-50{ }^{\circ} \mathrm{C}\right)$ with optimum temperature at $35^{\circ} \mathrm{C}$

Table (1). Determination of optical density and stander deviation of different temperature at which bacterial growth occur.

\begin{tabular}{|l|l|}
\hline Temperature & O.D. (600nm) \\
\hline $25^{\circ} \mathrm{C}$ & $1.225 \pm 0.070$ \\
\hline $30^{\circ} \mathrm{C}$ & $1.280 \pm 0.070$ \\
\hline $35^{\circ} \mathrm{C}$ & $1.330 \pm 0.028$ \\
\hline $40{ }^{\circ} \mathrm{C}$ & $1.180 \pm 0.042$ \\
\hline $45^{\circ} \mathrm{C}$ & $0.895 \pm 0.063$ \\
\hline $50{ }^{\circ} \mathrm{C}$ & $0.435 \pm 0.021$ \\
\hline
\end{tabular}




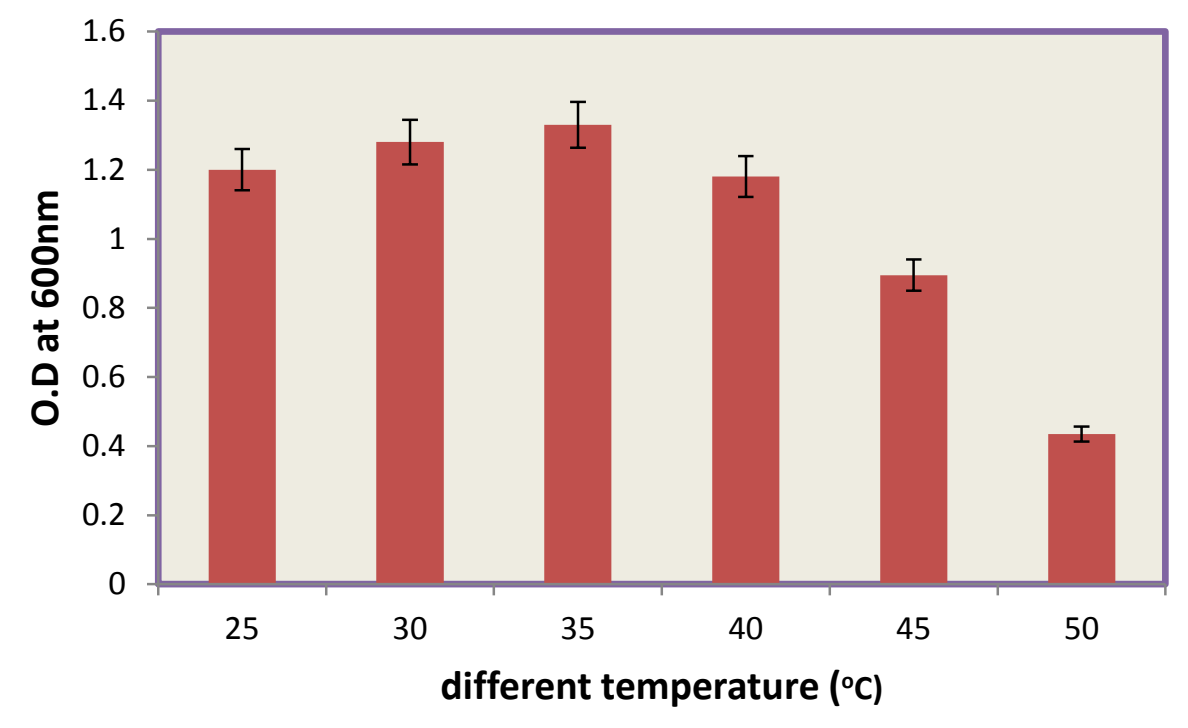

Fig (2). Effect of different temperature on the bacterial growth after $24 \mathrm{~h}$ growth.

ii. Effect of alkaline $\mathbf{p H}$ value on have optimal $\mathrm{pH}$ value at $\mathrm{pH} 9.0$, with bacterial growth.

The results obtained in the figure (3) and table (2), showed that, Halmonas sp. HA1 capable of growing until $\mathrm{pH} 11.0$ and optical density 0.4 that mean, Halomonas $s p$. HA1 characterized as alkaliphilic bacteria.

Table (2). Effect of $\mathrm{pH}$ values after $24 \mathrm{~h}$ growth.

\begin{tabular}{|c|c|}
\hline $\mathrm{pH}$ & O.D (600nm) \\
\hline 7.4 & $0.295 \pm 0.007$ \\
\hline 8.0 & $0.325 \pm 0.035$ \\
\hline 9.0 & $0.445 \pm 0.035$ \\
\hline 10 & $0.290 \pm 0.014$ \\
\hline 11 & $0.065 \pm 0.021$ \\
\hline
\end{tabular}




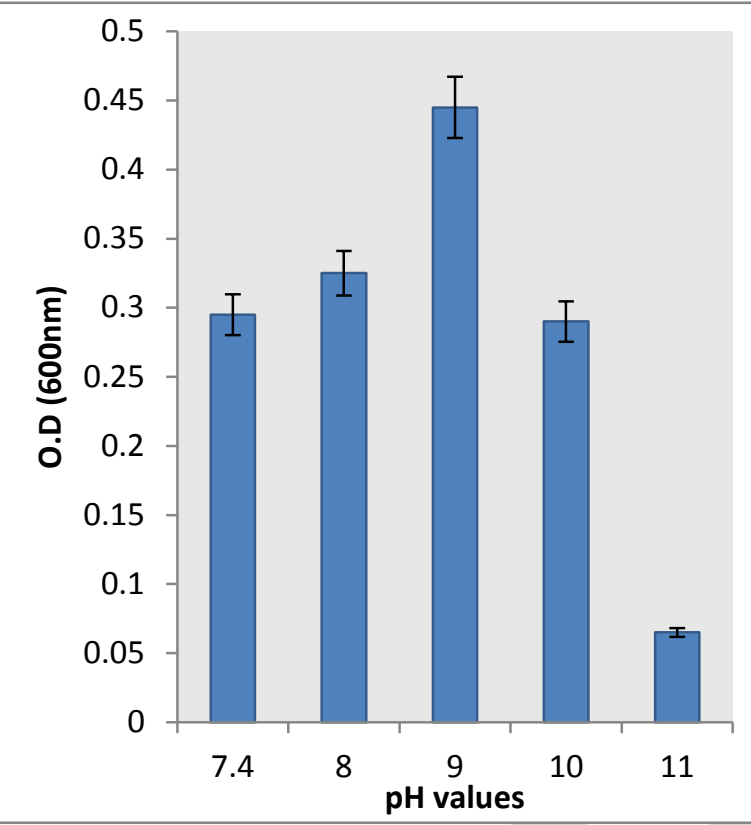

Fig (3). Effect of alkaline $\mathrm{pH}$ value after $24 \mathrm{~h}$ growth.

iii. Effect of different salt (4\%-10\%) $\mathrm{NaCl}$ with optical density of concentrations on the bacterial growth. $\quad(1,07-1,17)$ after $24 \mathrm{~h}$ growth. This strain

The results obtained in figure (4) and table (3) showed that strain have the ability to grow until $20 \% \mathrm{NaCl}$ with optical density of 0.26 after $24 \mathrm{~h}$ growth. The optimal salt concentration was in the range cannot grow without addition $\mathrm{NaCl}$ to the medium, that means Halomonas HA1 consider obligate moderately halophilic bacteria.

Table (3). Effect of different salt concentration after $24 \mathrm{~h}$ growth.

\begin{tabular}{|c|c|}
\hline Salt concentration & O.D. $(600 \mathrm{~nm})$ \\
\hline $1.0 \%$ & $0.120 \pm 0.018$ \\
\hline $1.5 \%$ & $0.877 \pm 0.063$ \\
\hline $2.5 \%$ & $0.920 \pm 0.028$ \\
\hline $4.0 \%$ & $1.075 \pm 0.106$ \\
\hline $6.0 \%$ & $1.155 \pm 0.063$ \\
\hline $8.0 \%$ & $1.215 \pm 0.049$ \\
\hline $10 \%$ & $1.170 \pm 0.024$ \\
\hline $12 \%$ & $0.940 \pm 0.058$ \\
\hline $14 \%$ & $0.775 \pm 0.106$ \\
\hline $16 \%$ & $0.575 \pm 0.116$ \\
\hline $18 \%$ & $0.430 \pm 0.028$ \\
\hline $20 \%$ & $0.260 \pm 0.084$ \\
\hline
\end{tabular}




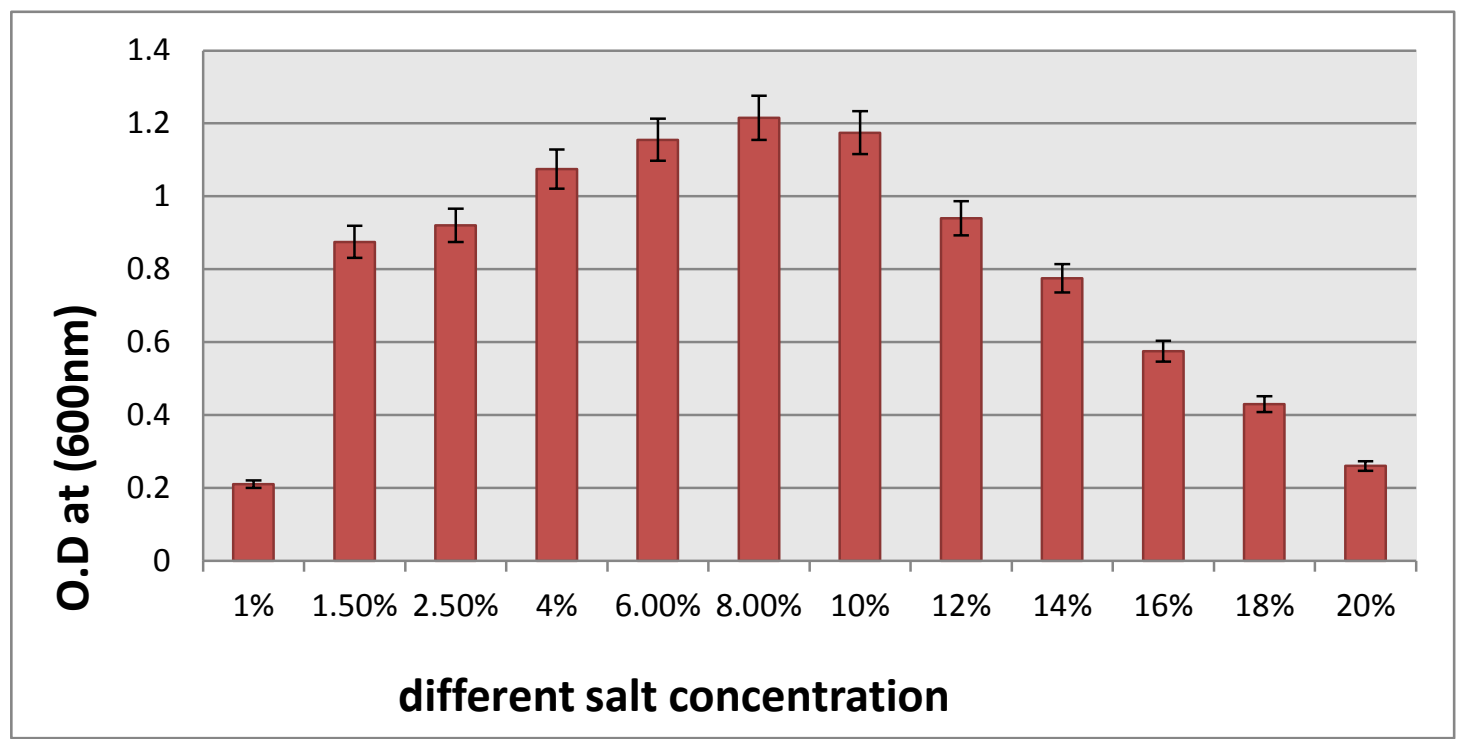

Fig (4). Effect of different salt concentration on bacterial growth after $24 \mathrm{~h}$ growth.

\section{DISCUSSION}

Extremophiles, able to live in unusual habitats and can potentially serve in variety of industrial applications (Burg, 2003). Major categories of extremophiles include halophiles, alkaliphiles, acidophiles, thermophiles and haloalkaliphiles while, the group of bacteria able to grow under alkaline conditions in the presence of salt are referred as haloalkliphiles.

In this study the moderately halophilic Gram negative bacteria related to Halomonas species was isolated from Wadi El Natrun hamra lake and their phenotypic and genotypic characteristics were studied. Halomonas is the largest genus in the family Halomonadaceae which originally proposed by Franzmann et al., (1988), belongs to Gamma proteobacteria and encompasses more than 76 recognized species untile 2013 (Oren and Ventosa, 2013).

The majority of Gram negative isolates were members of the Gamma subdivision of the proteobacteria, including many proteolytic organisms related to members of the genus Halomonas (DuckWorth et al., 2000). About thirty Halomonas species are capable of growing in salt concentrations of between $1 \%$ and $20 \% \mathrm{w} / \mathrm{v}$ and appear to be the commonest moderately halophilic inhabitants of saline environments, having been isolated from saline soils and water all over the world (Euzeby,2004 ; Ventosa et al., 1998).

The isolated Halomonas strain HA1 show growth inhibition on rich media without $\mathrm{NaCl}$ addition this indicates obligatory halophilic behavior. In contrast, the halotolerant bacteria do not require $\mathrm{NaCl}$ for growth although they grow in high salinity and in environments devoid of high concentration of salt. Halophiles can be classified into three groups based on their response to $\mathrm{NaCl}$, a) Slight halophiles which grow optimally at $2-5 \% \mathrm{NaCl}(0.2-$ $0.85 \mathrm{M})$. b) The moderate halophiles show rapid growth at 5-20\% $\mathrm{NaCl}(0.85-3.4 \mathrm{M})$. c) The extreme halophiles which optimally grow at $20-30 \% \mathrm{NaCl}$ (3.4-5.1 M), (Ollivier et al., 1994).

Haloalkaliphilic microorganisms possess special adaptation mechanisms to survive and grow under salinity and alkaline $\mathrm{pH}$, Different halophilic archaea and bacteria including Halomonas species, accumulate poly- $\beta$-hydroxyalkanoates (carbon and energy storage materials) to cope with nutrient-depleted conditions (Simon-Colin et al., 2008; Kulkarni et al., 2011). Also, some halophilic strains develop specific osmoadaptation mechanisms to prevent molecular damage from cellular dehydration. These mechanisms include (i) transmembrane 
exchange of salts to balance osmotic pressure through specific membrane transport proteins and (ii) accumulation of protective compatible solutes such as betaine or ectoine. Halomonas species are known to accumulate compatible solutes by uptake and/or by synthesis (Zhu et al., 2011).

The effect of different $\mathrm{pH}$ on growth of isolated Halomonas strain HA1 show optimal growth at $\mathrm{pH} 9$ with optical density of 0.4 at $600 \mathrm{~nm}$. the bacteria growth can be detected until $\mathrm{pH} 11$ with optical density of 0.06 at $600 \mathrm{~nm}$. Alkaliphilic bacteria

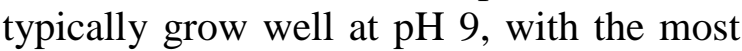

\section{CONCLUSION}

The isolated strain HA1 was a member of Halomonas sp. as it was demonstrated by $16 \mathrm{~S}$ rDNA sequence analysis. The registration accession number in gene bank was KT223026. This strain had the ability to give growth until $20 \%$ $\mathrm{NaCl}$ and $\mathrm{pH}$ 11. The bacterial growth

\section{REFERENCES}

Abd-el-Malek, Y. Rizk, S.G. (1963). Bacterial sulfate reduction andthe development of alkalinity. III. Experiments under natural conditions in the Wadi An Natrun. J Appl Microbiol. 26: 2026.

Amany G. T.(1999). Inland saline lakes of Wadi El Natrun depression, Egypt. International Journal of Salt Lake Research.. 8: 149-169.

Burg, B.(2003). Extremophiles as a source for novel enzymes. Current Microbiology. 6:213- 218.

Chang, Y.J. ; Stephen, J.R. ; Richter, A.P. ; Venosa, A.D. ; Bruggemann. J. ; Macnaughton, S.J. Kowalchuk, G.A. ; Haines, J.R. ; Kline, E. ; White, D.C. (2000). Phylogenetic analysis of aerobic freshwater and marine enrichment cultures efficient in hydrocarbon degradation: effect of profiling method. Journal of Microbiological Methods. 40:19-31. extremophilic strains growing up to $\mathrm{pH}$ values as high as $\mathrm{pH} 10-13$ this indicate that this stain is extremely alkaliphilic (Horikoshi, 1999). the ATP synthases of alkaliphilic bacteria at external $\mathrm{pH}$ values $>10$ is highly affected with proton motive force, which is posited to provide the energetic driving force for ATP synthesis. this condition accumulate too low synthesized ATP ( Hicks et al., 2010). Alkaliphilic bacteria overcome high $\mathrm{pH}$ outside cell by possessing special mechanism of ATP synthesis (preiss et al., 2015).

pattern show obligatory dependence on $\mathrm{NaCl}$ addition, that mean this strain considered as obligatory halophilic bacteria. The isolate demonstrate high $\mathrm{pH}$ tolerance until $\mathrm{pH} 11$ and optimal growth at $\mathrm{pH} 9$.

Recommended,require more studies on that strain to show the important enzymes that found in it and its use in the different manufacture.

Duckworth, A. W., Grant, W. D., Jones, B. E., Meijer, D., Márquez, M. C., \& Ventosa, A.

(2000). Halomonas magadii sp. nov., a new member of the genus Halomonas, isolated from a soda lake of the East African Rift Valley.Extremophiles, 4(1):53-60.

Euzeby, J.P. (2004). List of bacterial names with standing in nomenclature, Available from http://www.bacterio.cict.fr/

Feng, J.P. ; Zhou, Y. ; Zhou, S. and Liu Rhodes, K.W.(2005). Halorubrum alkaliphilum sp. nov., a novel haloalkaliphile isolated from a soda lake in Xinjiang, China. International Journal of Systematic Evolutionary Microbiology. 55:149-152.

Franzmann, P. D. ; Wehmeyer, U. and Stackebrandt, E. (1988). Halomonadaceae fam. nov., a new family of the class Proteobacteria to accommodate the genera Halomonas and Deleya. Syst Appl Microbiol 11, 16-19. 
Hicks, D.B. ; Liu, J. ; Fujisawa, M. ; Krulwich, T. A.(2010). F1F0-ATP synthases of alkaliphilic bacteria; lessons from their adaptations. Biochimica et Biophysica Acta 1797 (1362-1377).

Horikoshi, K. (1999). Alkaliphiles: Some application of their products for biotechnology. Microbiol. Mol. Biol. Rev. 63 (4): 735-750.

Joshi R.(2006). Extracellular Enzymes from halophilic and haloalkaliphilic bacteria isolated from seawater along the coastal Gujarat. Ph.D diss. Saurashtra University.

Kerkar, S. (2004). Ecology of hypersaline microorganisms. Marine microbiology: facets and opportunities, 3747.

Kulkarni, S. O. ; Kanekar, P. P. ; Joq, J. P. ; Nilegaonkar, S. S. ; Sarnaik, S. S. and Kshirsagar, P. R. (2011). Characterisation of copolymer, poly hydroxybutyrate co-

hydroxyvalerate (PHB co-PHV) produced by Halomonas campisalis MCM B-1027., its biodegradability and potential application. Biores. Technol. 102, 66256628.

Lanyi, J.K.(1974). Salt dependent properties of proteins from extremely halophilic bacteria. Bacteriol Rev. 38:272290.

Murray, R.G.E. ; Doetsch, R.N. and Robinow, C.F. (1994). Determinative and cytological light microscopy. In Methods for General and Molecular Bacteriology, pp. 21-41.

Noha, M. M. ; Soad H. A. and Juergen, W. (2007). Novel and Unexpected Prokaryotic Diversity in Water and Sediments of the Alkaline, Hypersaline Lakes of the Wadi An Natrun, Egypt. Springer Science \& Business Media, LLC. 54: 598-617.

Ollivier, B. ; Caumette, P. ; Garcia, J. L. and Mah, R. A. (1994).Anaerobic bacteria from hypersaline environments. Microbiology Reviews 58, (1): 27-38.
Oren, A. and Ventosa, A. (2013). Subcommittee on the taxonomy of Halobacteriaceae and

Subcommittee on the taxonomy of Halomonadaceae Int. J. Syst. Evol. Microbiol. 63: 3540-3544.

Preiss , L. ; Hicks, D. B. ; Suzuki, S. ; Krulwich, T. A.(2015). Alkaliphilic bacteria with impact on industrial applications, concepts of early life forms, and bioenergetics of ATP synthesis. Frontiers in Bioengineering and Biotechnology | www.frontiersin.org vol.3 Art 75.

Sayed, M.F. and Abdo, M.H. (2009). Assessment of Environmental Impact On, Wadi El-Natrun Depression Lakes Water, Egypt. World J. Fish \& Marine Sci. 1 (2): 129-136.

Simon-Colin, C. ; Raguénès, G. ; Cozien, J. and Guezennec, J. G. (2008). Halomonas profundus sp. nov., a new PHA-producing bacterium isolated from a deep-sea hydrothermal vent shrimp. J. Appl. Microbiol. 104, 1425-1432.

Singh, S. P. ; Purohit, M. K. ; Raval, V. H. ; Pandey, S. ; Akbari, V. G., and Rawal, C. M. (2010). Capturing the potential of Haloalkaliphilic bacteria from the saline habitats through culture dependent and metagenomic approaches. Current research, technology and education topics in applied microbiology and microbial biotechnology, 81-87.

Smibert, R.M. and Krieg, N.R. (1994). Phenotypic characterization In Methods for General and Molecular Bacteriology, pp. 607-654.

Ventosa, A. ; Nieto, J.J. and Oren, A. (1998) Biology of moderately halophilic aerobic bacteria. Microbiol. Mol. Rev. 62, 504-544.

Zhu, D. ; Wang, C. ; Hosoi-Tanabe, S. ; Zhang, W. and Nagata, S.( 2011). The synthesis and role of hydroxyectoine in halophilic bacterium Halomonas ventosae DL7. Afr. J. Microbiol. Res. 5: 2254-2260. 